\title{
Ogallala aquifer depletion: economic impact on the Texas high plains
}

\author{
Bonnie L. Terrell ${ }^{\mathrm{a}}$, Phillip N. Johnson ${ }^{\mathrm{b}, *}$, Eduardo Segarra ${ }^{\mathrm{b}}$ \\ ${ }^{a}$ Agricultural Investments for Mutual of New York, Lubbock, TX, USA \\ ${ }^{\mathrm{b}}$ Department of Agricultural \& Applied Economics, Texas Tech University, Box 42132, Lubbock, TX 79409-2132, USA
}

Received 2 May 2001; received in revised form 26 November 2001; accepted 19 December 2001

\begin{abstract}
The impacts of the depletion of the Ogallala aquifer on the economy of the Southern High Plains of Texas were estimated by predicting future cropping patterns over a 30 -year time horizon as the saturated thickness of the aquifer declines. Increased adoption of sprinkler irrigation methods, increased cotton acreage, and a shift to dryland production were the main responses found to declining water availability in the region. As the Ogallala aquifer is depleted, the region could experience a downturn in agricultural production with possible negative impacts on the regional economy assuming no other offsetting exogenous shocks to the economy. (C) 2002 Elsevier Science Ltd. All rights reserved.
\end{abstract}

Keywords: Ogallala aquifer; Economic impacts; Depletion; Dynamic programming

\section{Introduction}

The economy of the Southern High Plains (SHP) region of Texas (defined here as a 19-county region within the Texas High Plains, Fig. 1) heavily relies on the agricultural industry to sustain economic growth and development. This region has approximately 1.01 million ha of irrigated cropland drawing water from the Ogallala aquifer (USDA, 1999). The 1997 production value of the four major field crops (cotton, wheat, corn, and grain sorghum) grown in the SHP totaled $\$ 1100$ million, $72 \%$ or $\$ 818$ million of which can be directly attributed to irrigated crop production. This region produces $51 \%$ of the cotton, $28 \%$ of the corn, $22 \%$ of the wheat, and $18 \%$ of the grain sorghum produced in Texas (Texas Agricultural Statistics Service, 1998).

While cotton is the primary crop grown in the SHP region, feed grain production from irrigated corn and grain sorghum has established this region as the leading cattle feeding area in the nation.

\footnotetext{
*Corresponding author. Tel.: + 1-806-742-0261; fax: + 1-806-742-1099.

E-mail address: phil.johnson@ttu.edu (P.N. Johnson).
} 


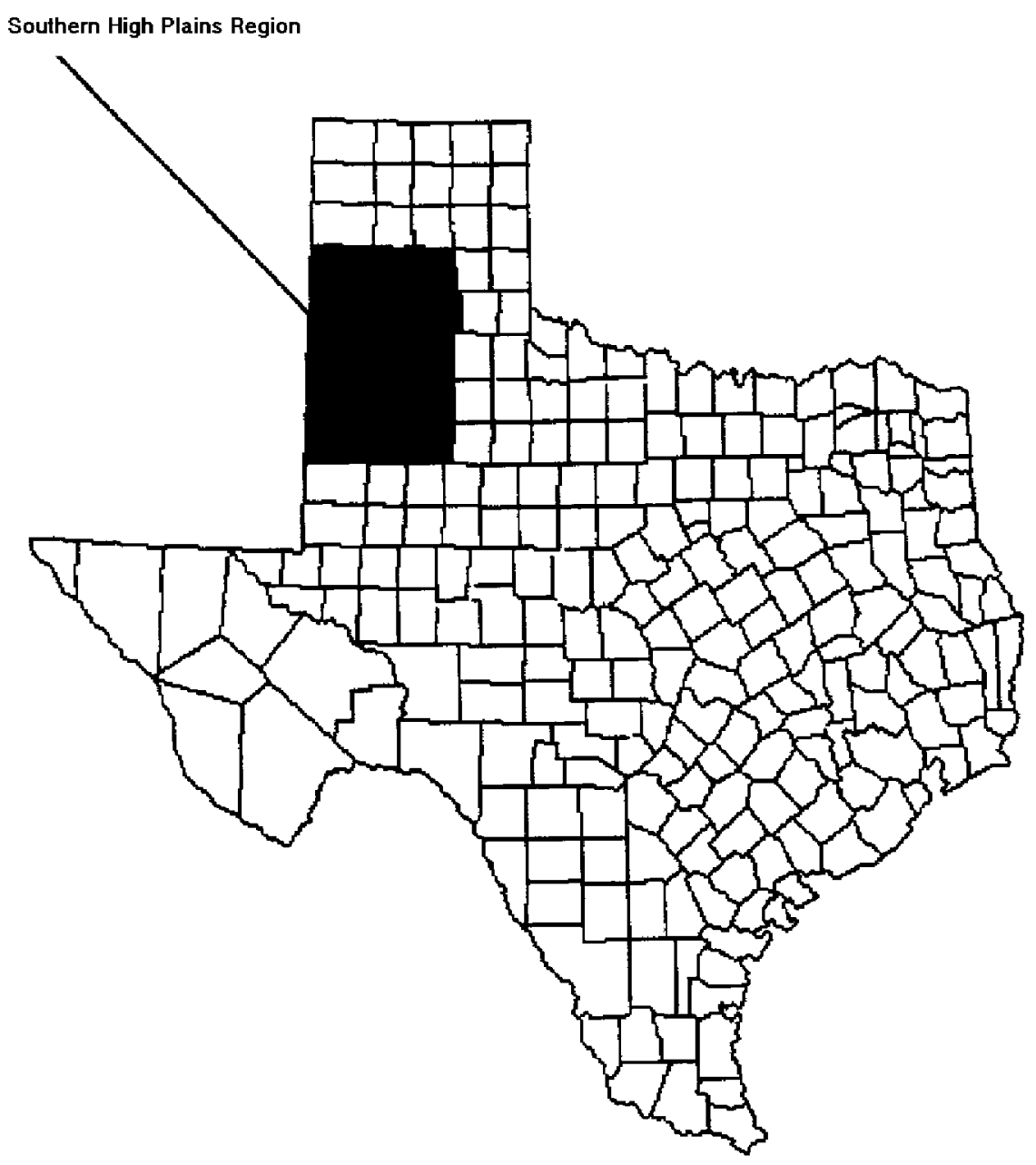

Fig. 1. The Southern High Plains Region of Texas.

In 1997, Texas produced $25 \%$ of the fed beef in the United States, with $63 \%$ of the fed beef in Texas being marketed from feedlots in the SHP (Texas Agricultural Statistics Service, 1998). In 1997, the total cash value for cattle and calf production in Texas was estimated at $\$ 5800$ million, with the beef industry comprising $44 \%$ of the total agricultural receipts in Texas (Texas Agricultural Statistics Service, 1998). The economy of the SHP is highly dependent on the agribusiness sector.

Agribusiness in the SHP is composed of many interdependent components that sustain and enhance economic growth for the region. In addition to the commodity production sectors within the economy, a major element of this system is the infrastructure supporting agribusiness. This infrastructure includes grain elevators, cotton gins, cattle feedlots, farm machinery and equipment dealers, trucking firms, production input suppliers (seed, fertilizer, chemicals), meat packing plants, cotton oilseed processing plants and textile mills. The agribusiness sector contributes to the 
production, marketing, processing and transporting of the agricultural products produced in the region and plays a primary role in the contribution of economic value to the regional economy.

Irrigated agriculture in the SHP is dependent on underground water pumped from the Ogallala aquifer. The Ogallala is a major aquifer system that stretches across parts of eight Great Plains states, from South Dakota southward to Texas, with the SHP located at the extreme southern extent of the aquifer. The Ogallala is a water-bearing sand and gravel formation with varying saturated thickness across the region (Texas Water Development Board, 1997). The development of irrigation in the SHP began in the 1940s and developed rapidly. Pumpage for irrigation in the region was estimated at 492,000 ha $\mathrm{m}$ ( 4 million ac ft) in 1949 (High Plains Underground Water Conservation District, 1997), increasing to 697,410 ha $\mathrm{m}$ (5.67 million ac ft) by 1979 as irrigation was fully developed in the region, and declined to 576,870 ha $\mathrm{m}$ (4.69 million ac ft) in 1989 (Texas Water Development Board, 1993). The heavy pumpage has outstripped the natural recharge of the aquifer, thereby causing declining water levels, particularly in heavily irrigated areas. The annual effective recharge of the Ogallala aquifer in the Texas High Plains region amounts to approximately 53,986 ha $\mathrm{m}(438,910 \mathrm{ac} \mathrm{ft})$, which represents only $7.4 \%$ of the 1994 total pumpage of 725,700 ha m (5.9 million ac ft) (Texas Water Development Board, 1997).

The SHP is currently facing declining water reserves and reduced irrigation well yields from depletion of the Ogallala aquifer after nearly a half century of heavy irrigation pumping demand. It is estimated that $30-35 \%$ of the pre-development underground water supplies within the Ogallala aquifer have already been mined (Segarra \& Feng, 1994). The saturated thickness of the aquifer, which is the thickness of the water-bearing formation, has declined appreciably across the region with resulting effects on pumping lifts and well yields. The effects on the cropland acreage under irrigation and available levels of water per ha are becoming more pronounced as the aquifer is depleted. Irrigated cropland acreage in the SHP region has declined from 1.58 million ha in 1958 to 1.13 million ha in 1994 (Texas Water Development Board, 1996).

Farmers in the region have adopted more efficient irrigation methods to adjust to the changing level of available irrigation. The number of center pivot sprinkler irrigation systems located in the 15 counties of the High Plains Underground Water Conservation District No. 1, have increased from 4474 systems in 1990 (High Plains Underground Water Conservation District, 1996) to 11,287 systems in 1998 (High Plains Underground Water Conservation District, 1999). This transition from furrow irrigation systems to center pivot sprinkler systems was primarily due to the higher water application efficiency with the center pivot systems. However, even with the adoption of more efficient irrigation methods, many farms may be forced to return to dryland farming with its accompanying loss in revenues as the aquifer continues to decline. Given this situation, there is substantial interest in the potential impacts resulting from the depletion of the Ogallala aquifer on the SHP economy. Therefore, the objective of this study was to evaluate the impacts of changes in agricultural production patterns in the SHP due to decreased availability of groundwater supplies on the region's economy.

\section{Methods and procedures}

To estimate the economic implications of the depletion of the Ogallala aquifer for the defined study region, two analytical tools were utilized. Dynamic linear programming models were used 
to estimate optimal cropping patterns for the study region over a 30-year time horizon. IMPLAN, an input-output modeling program, was used to estimate the economic impacts resulting from changes in crop production within the region as the availability of irrigation water supplies decline.

\subsection{The dynamic optimization model}

Dynamic programming models were constructed for each of the 19 counties within the study region to estimate future cropping patterns, optimal groundwater use, irrigation technology adoption, saturated thickness, and pumping lifts. The partial equilibrium models were a modification of Feng's dynamic programming model used to estimate irrigation technology adoption in the Texas High Plains (Segarra \& Feng, 1994). Feng's model was modified to include constraints for the rate of crop and irrigation technology adjustment, percent of cotton in the crop mix, and the inclusion of a wheat enterprise. Crops included in the study were irrigated and dryland cotton, grain sorghum, wheat, and irrigated corn. Irrigation technologies included conventional furrow, low-energy precision application (LEPA) sprinkler, and dryland farming.

The operating cost data were taken from Texas Crop Enterprise Budgets for the South Plains District for the 1996 crop year (Texas Agricultural Extension Service, 1996). Commodity prices were the average prices received by farmers for 1994-1996 as reported by the Texas Agricultural Statistics Service (Texas Agricultural Statistics Service, 1994-1996). Crop yields and initial crop acreage were the average for each county for 1994-1996 as reported by the Texas Agricultural Statistics Service (Texas Agricultural Statistics Service, 1994-1996).

The per unit cost of pumping water was expressed as a function of pumping lift and well yield. Pumping lift increases and well yields decline as the saturated thickness of the aquifer decreases. Therefore, recursive hydrological equations were included in the model to describe the dynamics of aquifer depletion on pumping cost and irrigation availability (Feng, 1992; Segarra \& Feng, 1994). Hydrological characteristics were specified for each county to reflect differences in the aquifer across the region. Constraints were included within the models to allow a gradual transition in both crops and irrigation technologies due to budget constraints for producers and the time needed to adopt new technologies. These constraints allowed for annual shifts of no more than $15 \%$ between crops and $5 \%$ between irrigation technologies (the average adoption of sprinkler technology within the 19 counties over the past 10 years has been $1.6 \%$ annually).

The relative profitability of crops varied across the region, given the relative yields and irrigation costs. In the northern counties of the region, corn and cotton were the most profitable, while in the southern area, cotton was most profitable. Crops produced under sprinkler irrigation tended to be more profitable than with furrow irrigation. A constraint was included in the model that restricted the percentage of total cropland that could be in cotton production. Cotton production requires less water than most of the other crops included in the analysis, and is the most profitable crop under most circumstances. Therefore, under unconstrained conditions, the optimization models allocated $90 \%$ or more of the available cropland to cotton production in the majority of the counties within the study region. However, it was unrealistic to expect the study region to convert largely to cotton production since different areas of the region possess characteristics that are unique in terms of the composition of crops grown. Therefore, it was necessary to include constrains on cotton percentages with the model. The three northernmost 
counties of the region were given a restriction of $50 \%$ of total cropland in cotton production; the central counties were restricted to $75 \%$ of the total cropland to be in cotton production; and the southernmost counties were free to produce up to $90 \%$ of the available cropland in cotton. These percentages were based on the current proportions of cotton in each area, which are $0-2.5 \%$ in the northern counties, $19-59 \%$ in the central counties, and $60-86 \%$ in the southern counties.

Nineteen dynamic optimization models to predict crop acreage were run for the 30-year time horizon using county-specific data. The output from these models provided the percentages of total acreage allotted to each crop and irrigation system per county. These percentages were then applied to the total cropland acreage within each county to estimate the acreage of each crop produced under furrow irrigation, sprinkler irrigation, or dryland conditions within the county.

The production values of this acreage over the 30 -year time horizon were calculated using the 1994-1996 average per ha yields and prices to match the use of the 1995 IMPLAN database used in the input-output analysis. The calculated dollar values represented the annual agricultural production values for each crop. The use of constant prices throughout the time horizon allowed the changes in cropping patterns due to changes in irrigation capacity related to declining water availability to be the deciding factor driving economic activity.

\subsection{Specification of the dynamic optimization model}

The objective function of the optimization models was to maximize the net present value of net returns to land, management, groundwater stock, risk, and investment. Net returns may be expressed as:

$$
\mathrm{NR}_{t}=\sum_{i} \sum_{k} \Theta_{i k t}\left\{\left(P_{i t} Y_{i k t}\right)-C_{i k t}\left(\mathrm{WP}_{i k t}, X_{t}, \mathrm{ST}_{t}\right)\right\},
$$

where $i$ represents the crops grown; $k$ represents irrigation technologies; $t$ represents time, $\Theta_{i k t}$ is the percentage of crop $i$ produced by irrigation technology $k$ in time $t ; P_{i t}$ represents the price of crop $i$ in time $t ; Y_{i k t}$ represents the yield of crop $i$ produced under irrigation technology $k$ in time $t$; $C_{i k t}$ represents the cost of production of crop $i$ produced under irrigation technology $k$ in time $t$; $\mathrm{WP}_{i k t}$ represents the ha $\mathrm{m}$ of water applied to crop $i$ under irrigation technology $k$ in time $t ; X_{t}$ represents the pumping lift in time $t ; \mathrm{ST}_{t}$ represents the saturated thickness of the aquifer in time $t$; and $\mathrm{NR}_{t}$ represents the net returns in time $t$. Costs include the variable cost of crop production, investment and maintenance cost of the irrigation system, and pumping cost. The objective function was optimized for a 30 -year planning horizon and may be expressed as:

$$
\text { MAX NPVR }=\sum_{t=1}^{30} \mathrm{NR}_{t}(1+r)^{-t}
$$

where NPVR is the net present value of returns and $r$ is the discount rate. A value for $r$ of $2 \%$ was used in the models, which represents a social discount rate.

$$
\operatorname{MAXNPVR}=\sum_{i} \sum_{k} \sum_{t} \Theta_{i k t}\left\{P_{i t} Y_{i k t}-C_{i k t}\left(\mathrm{WP}_{i k t}, X_{t}, \mathrm{ST}_{t}\right)\right\}(1+r)^{-t}
$$


Subject to:

$$
\begin{aligned}
& \mathrm{ST}_{t+1}=\mathrm{ST}_{t}-\left[\left(\sum_{i} \sum_{k} \Theta_{i k t} \mathrm{WP}_{i k t}\right)-R_{t}\right](A s), \\
& X_{t+1}=X_{t}+\left[\left(\sum_{i} \sum_{k} \Theta_{i k t} \mathrm{WP}_{i k t}\right)-R_{t}\right](A s), \\
& \mathrm{GPC}_{t} \leqslant[(800 \mathrm{PHR}) /(450 \mathrm{CLA})]\left(\mathrm{ST}_{t} / 210\right)^{2}, \\
& \mathrm{WT}_{t} \leqslant \mathrm{GPC}_{t}, \\
& \sum_{i} \sum_{k} \Theta_{i k t} \leqslant 1 \quad \text { for all } t, \\
& \mathrm{PC}_{t}=\left[0.0014539\left(X_{t}+(2.31 \mathrm{PSI}) U_{t}\right) /(\mathrm{PE})\right] \mathrm{WP} i k t \\
& \sum_{i} \sum_{k} C_{i k t}=\mathrm{MC}_{k t}+\mathrm{DP}_{k t}+\mathrm{LC}_{i k t}+\mathrm{VC}_{i k t}+\mathrm{PC}_{i k t}+\mathrm{HC}_{i k t}, \\
& \sum_{i} \Theta_{i t} \geqslant 0.85 \Theta_{i t-1}, \\
& \sum_{k} \Theta_{k t} \geqslant 0.95 \Theta_{k t-1}, \\
& \sum_{\cot } \Theta_{\mathrm{cot} t} \leqslant \mathrm{CT} \mathrm{AC}_{i} \\
& X_{t}=1=X_{1}, \\
& \mathrm{ST}_{t}=1=\mathrm{ST}_{1}, \\
& \Theta_{i k t} \geqslant 0 . \\
& \mathrm{Al},
\end{aligned}
$$

The objective function expressed in Eq. (3) is the substitution of Eq. (1) into Eq. (2). Eqs. (4) and (5) are the equations of motion which update the two state variables, saturated thickness ( $\left.\mathrm{ST}_{t}\right)$ and pumping lift $\left(X_{t}\right)$, where $R_{t}$ is the average net recharge annually in ha $\mathrm{m}, A$ is the acreage of the county underlain by the aquifer, and $s$ is the storage coefficient of the aquifer. Eqs. (6) (8) relate to the water availability, water pumpage and land availability, respectively, where $\mathrm{GPC}_{t}$ is the annual gross pumping capacity in ha $\mathrm{m}$ per ha, CLA and PHR represent the county-specific information on cropland acreage per irrigation well and irrigation season pumping hours, respectively, and $\mathrm{WT}_{t}$ is the total ha $\mathrm{m}$ of water pumped (defined as the sum of $\Theta_{i k t} \mathrm{WP}_{i k t}$ ). Eq. (9) is the pumping cost function, where $\mathrm{PC}_{t}$ is pumping cost, PSI is pounds per square inch of pumping head, $U_{t}$ is the cost of natural gas (assumed to be $\$ 3 / \mathrm{mcf}$ ), and $\mathrm{PE}$ is the pumping efficiency. Eq. (10) is the cost function, where $\mathrm{MC}_{k t}$ is the maintenance cost for irrigation system $k$ in time $t, \mathrm{DP}_{k t}$ is the depreciation cost of irrigation system $k$ in time $t, \mathrm{LC}_{i k t}$ is the labor cost for crop $i$ under irrigation system $k$ in time $t, \mathrm{VC}_{i k t}$ is the variable cost of production for crop $i$ under 
irrigation system $k$ in time $t$, and $\mathrm{HC}_{i k t}$ is the harvest cost per ha for crop $i$ under irrigation system $k$ in time $t$. Eqs. (11) and (12) limit annual shifts in crop acreage and irrigation technologies to $15 \%$ and $5 \%$, respectively. Eq. (13) limits the proportion of a county's crop acreage that can be in cotton, where CT is the proportion of cotton acreage applicable to a particular county and $\mathrm{AC}$ is the total crop acreage for the respective county. Eqs. (14) and (15) set the initial conditions of pumping lift and saturated thickness. Eq. (16) specifies that the values of decision variables are non-negative.

\subsection{The IMPLAN model}

An input-output model using IMPLAN (IMpact Analysis for PLANning) was constructed to estimate how the SHP regional economy would be affected as the saturated thickness of the Ogallala aquifer diminishes. The economic activity generated by the production of cotton, wheat, corn, and grain sorghum was estimated and analyzed using IMPLAN for the 30-year time horizon in 5-year increments. Olson and Lindall (1997) describe the input-output analysis as involving the assessment of change in overall economic activity resulting from a corresponding change in one or several industries. The IMPLAN analysis permits the estimation of economic impacts at a given point in time and, by combining the results of a succession of years, estimated trends in economic activity can be discerned.

The input-output analysis is based on the assumption that inter-industry transactions (production for consumption) plus final demand equals the total economic activity in an economy. Therefore, the total economic activity is a function of final demand (Olson \& Lindall, 1997). Industries contribute goods and services to final demand or to those activities triggered by final consumption. In calculating the effects of a change in final demand, the input-output analysis provides output, income, employment and value-added impact analyses with which to quantify "shocks" to the economy. The IMPLAN program only allowed the analysis of backward linkages and not forward linkages. Therefore, the changes in economic impacts to industries within the region that utilize the crops produced, such as the feedlot sector, cannot be directly measured with this method. In addition, the levels of imports and exports of goods and services into and out of the region are estimated using national relationships and may differ from actual levels for the region.

Final demand within the cotton, feed grain (corn and grain sorghum), and food grain (wheat) sectors of the regional economy were derived using the estimated production values from cotton, grain sorghum, corn, and wheat in the study region. The model was calculated using the 1995 IMPLAN data set (Minnesota IMPLAN Group, Inc., 1997), which was localized using countylevel statistics for 1995 to update the regional production values for cotton, wheat, corn, and grain sorghum. These values were used to update the IMPLAN sectors involved which included the cotton, food grain, and feed grain sectors. Associated elements within the regional data table were scaled proportionately to maintain the ratios between elements.

Estimated production values derived from the dynamic optimization models for 1996 served as a baseline because they represented the first year of optimization. Impact analysis was conducted in 5-year increments over the 30-year time horizon using changes in crop acreage derived from the dynamic optimization models. The results of the analysis were six "snapshots" of the regional economy into the future. 


\section{Results}

The estimation of the economic impacts resulting from depletion of the Ogallala aquifer consisted of a three-step process. First, estimated changes in cropping patterns and hydrological characteristics were obtained from the dynamic optimization models for the 19 counties of the study area. Then, crop production values were calculated based on the expected changes in cropping patterns. Finally, regional economic impacts were estimated using the input-output model based on the projected changes in crop production values over time as adjustments are made in response to declining water availability.

\subsection{Cropping patterns and hydrological characteristics}

Decreasing saturated thickness of the aquifer, increasing irrigation well pumping lifts, and declining gross pumping capacity over the 30-year time horizon illustrate the dynamic nature of the Ogallala aquifer in this region. Table 1 presents the initial values, estimated values for the year 2025, and percentage changes for saturated thickness and pumping lifts over the 30-year time horizon for each county in the study region. As indicated in Table 1, the saturated thickness and pumping lifts vary considerably across the study area. The initial regional weighted-average saturated thickness and pumping lifts were $25.1 \mathrm{~m}(82.7 \mathrm{ft})$ and $51.5 \mathrm{~m}(169.4 \mathrm{ft})$, respectively. The

Table 1

Initial and estimated levels of saturated thickness and pumping lift capacity over the 30-year planning horizon

\begin{tabular}{|c|c|c|c|c|c|c|}
\hline \multirow[t]{2}{*}{ County } & \multicolumn{3}{|c|}{ Saturated thickness (m) } & \multicolumn{3}{|c|}{ Pumping lift (m) } \\
\hline & Initial & 2025 & $\%$ Change & Initial & 2025 & $\%$ Change \\
\hline Armstrong & 11.2 & 10.9 & -2.5 & 42.8 & 42.9 & 0.3 \\
\hline Bailey & 26.3 & 21.7 & -17.5 & 31.3 & 34.3 & 9.5 \\
\hline Briscoe & 29.8 & 27.5 & -7.5 & 71.1 & 73.4 & 3.2 \\
\hline Castro & 34.7 & 21.7 & -37.5 & 68.5 & 81.4 & 18.9 \\
\hline Cochran & 15.7 & 14.4 & -7.9 & 43.5 & 44.6 & 2.5 \\
\hline Crosby & 34.0 & 27.4 & -19.9 & 68.0 & 74.9 & 10.2 \\
\hline Deaf Smith & 28.3 & 22.6 & -20.2 & 63.2 & 68.9 & 9.0 \\
\hline Floyd & 29.9 & 21.1 & -29.3 & 71.1 & 79.8 & 12.2 \\
\hline Garza & 34.0 & 33.6 & -1.3 & 67.8 & 68.2 & 0.6 \\
\hline Hale & 32.1 & 21.8 & -32.0 & 57.9 & 67.9 & 17.3 \\
\hline Hockley & 14.4 & 11.3 & -21.6 & 38.6 & 41.9 & 8.6 \\
\hline Lamb & 28.3 & 18.0 & -36.3 & 42.9 & 53.1 & 23.9 \\
\hline Lubbock & 21.7 & 14.9 & -31.3 & 35.4 & 41.9 & 18.6 \\
\hline Lynn & 15.5 & 15.2 & -2.1 & 17.4 & 17.7 & 1.2 \\
\hline Parmer & 30.4 & 20.4 & -32.9 & 88.0 & 97.8 & 11.1 \\
\hline Randall & 19.9 & 18.4 & -7.7 & 52.8 & 55.2 & 4.5 \\
\hline Swisher & 35.0 & 29.1 & -16.8 & 68.4 & 74.3 & 8.6 \\
\hline Terry & 18.8 & 16.5 & -12.5 & 17.3 & 19.7 & 13.6 \\
\hline Yoakum & 18.8 & 16.6 & -12.0 & 43.5 & 45.7 & 5.2 \\
\hline Regional average & 25.1 & 19.6 & -22.1 & 51.5 & 56.9 & 10.6 \\
\hline
\end{tabular}


weighted-average decline in the saturated thickness of the aquifer over the time horizon for all counties in the region was $22.1 \%$, while the weighted-average pumping lift increased $10.6 \%$ for the region.

Table 2 presents the initial values, estimated values for the year 2025 , and percentage changes for gross pumping capacity over the 30 -year time horizon for each county in the study region. Gross pumping capacity represents the ha $\mathrm{m}$ of irrigation capacity available per ha of cropland for a given county and is a function of cropland per irrigation well, pumping hours, and saturated thickness. In the calculation of gross pumping capacity, the number of irrigation wells and the hours of pumping were held constant across the years. As indicated in Table 2, gross pumping capacity is expected to decrease by $43.6 \%$ by 2025 .

Table 3 presents the ha of cropland for dryland production and irrigated production under sprinkler and furrow irrigation technologies for initial values and estimated values for the year 2025. Dryland crop production in the region is expected to increase from $53.0 \%$ to $57.9 \%$ of crop acreage over the 30-year planning horizon. Furrow irrigation decreases to only $7.5 \%$ of cropland acreage, while sprinkler irrigation increases from $24.6 \%$ to $34.4 \%$ of cropland acreage over the period. The results indicate a significant transition toward sprinkler irrigation technologies, particularly in those counties with relatively high initial levels of furrow irrigation.

Castro, Lamb, Parmer, Hale, and Lubbock Counties experience the greatest change with regard to the aquifer characteristics presented in Tables 1 and 2. These counties tended to have higher

Table 2

Initial and estimated levels of gross pumping capacity over the 30 -year planning horizon

\begin{tabular}{llcc}
\hline County & \multicolumn{2}{l}{ Gross pumping capacity $($ ha m per ha of cropland) } \\
\cline { 2 - 4 } & Initial & 2025 & \% Change \\
\hline Armstrong & 0.12 & 0.11 & -2.13 \\
Bailey & 1.57 & 1.10 & -30.2 \\
Briscoe & 0.78 & 0.67 & -14.02 \\
Castro & 1.81 & 0.73 & -59.95 \\
Cochran & 0.38 & 0.33 & -13.42 \\
Crosby & 1.00 & 0.65 & -35.06 \\
Deaf Smith & 1.48 & 0.96 & -35.17 \\
Floyd & 1.16 & 0.59 & -47.78 \\
Garza & 0.83 & 0.81 & -2.53 \\
Hale & 1.54 & 0.73 & -52.72 \\
Hockley & 0.69 & 0.42 & -39.22 \\
Lamb & 1.81 & 0.76 & -58.25 \\
Lubbock & 1.21 & 0.59 & -51.48 \\
Lynn & 0.31 & 0.30 & -4.33 \\
Parmer & 1.54 & 0.71 & -53.74 \\
Randall & 0.58 & 0.51 & -13.29 \\
Swisher & 1.12 & 0.78 & -29.85 \\
Terry & 0.55 & 0.42 & -22.75 \\
Yoakum & 0.64 & 0.50 & -21.92 \\
Regional average & 1.12 & & -43.55 \\
\hline
\end{tabular}


Table 3

Initial and estimated levels of the percentage of cropland acreage under different irrigation technologies over the 30-year planning horizon

\begin{tabular}{|c|c|c|c|c|c|c|}
\hline \multirow{3}{*}{ County } & \multicolumn{6}{|c|}{ Percentage of cropland acreage } \\
\hline & \multicolumn{2}{|c|}{ Dryland } & \multicolumn{2}{|c|}{ Sprinkler } & \multicolumn{2}{|c|}{ Furrow } \\
\hline & Initial & 2025 & Initial & 2025 & Initial & 2025 \\
\hline Armstrong & 91.7 & 94.5 & 6.2 & 5.0 & 2.1 & 0.5 \\
\hline Bailey & 56.0 & 56.0 & 30.4 & 30.3 & 13.6 & 13.6 \\
\hline Briscoe & 65.1 & 65.1 & 8.0 & 27.8 & 26.9 & 7.2 \\
\hline Castro & 25.9 & 45.6 & 34.8 & 45.5 & 39.3 & 8.9 \\
\hline Cochran & 69.2 & 72.9 & 30.5 & 27.0 & 0.3 & 0 \\
\hline Crosby & 43.8 & 52.2 & 12.4 & 37.9 & 43.9 & 9.9 \\
\hline Deaf Smith & 47.3 & 54.7 & 22.7 & 25.8 & 30.1 & 6.8 \\
\hline Floyd & 41.3 & 57.8 & 5.3 & 30.1 & 53.5 & 12.1 \\
\hline Garza & 78.3 & 78.3 & 3.3 & 3.3 & 18.5 & 18.5 \\
\hline Hale & 17.2 & 48.0 & 21.5 & 38.2 & 61.3 & 13.9 \\
\hline Hockley & 52.5 & 67.6 & 32.3 & 28.9 & 15.2 & 3.4 \\
\hline Lamb & 27.6 & 40.8 & 52.9 & 54.8 & 19.6 & 4.4 \\
\hline Lubbock & 40.6 & 58.4 & 6.5 & 29.7 & 52.9 & 12.0 \\
\hline Lynn & 80.2 & 80.2 & 8.7 & 10.7 & 11.1 & 9.0 \\
\hline Parmer & 37.0 & 45.0 & 37.2 & 49.1 & 25.8 & 5.8 \\
\hline Randall & 67.5 & 67.5 & 8.8 & 25.7 & 23.7 & 6.8 \\
\hline Swisher & 53.2 & 53.2 & 8.7 & 38.2 & 38.2 & 8.6 \\
\hline Terry & 55.7 & 65.7 & 44.3 & 34.3 & 0 & 0 \\
\hline Yoakum & 48.1 & 59.5 & 50.4 & 40.4 & 0.5 & 0.1 \\
\hline Regional average & 53.0 & 57.9 & 24.6 & 34.4 & 28.4 & 7.5 \\
\hline
\end{tabular}

initial saturated thicknesses and gross pumping capacities, and greater initial acreage under irrigation. The decreasing saturated thickness for these counties over the time period result in greater-than-average declines in gross pumping capacity. As would be expected, the counties within the region where irrigation was most significant to crop production tended to have the most significant shifts toward dryland crop production as gross pumping capacity declined. For example, Castro County exhibited a $13.0 \mathrm{~m}(42.8 \mathrm{ft})$ decline in saturated thickness, a $37.5 \%$ decrease. Gross pumping capacity for Castro County decreased from 1.81 ha $\mathrm{m}$ ( $14.73 \mathrm{ac}$ in) to 0.73 ha $\mathrm{m}$ ( $5.9 \mathrm{ac}$ in), a $60.0 \%$ decrease. The effects of the aquifer depletion resulted in a shift in dryland acreage from $25.9 \%$ to $45.6 \%$ of total cropland acreage and a shift in the adoption of sprinkler irrigation methods from $34.8 \%$ to $45.5 \%$ of the total cropland acreage.

As irrigation water availability decreases, the options available to producers are to produce crops that utilized less irrigation water, adopt more efficient irrigation methods or to switch to dryland farming. Castro, Lamb, Parmer, Hale, and Lubbock Counties, all are expected to experience large increases in the proportion of dryland acreage over the time horizon. These increases are based on the transition from the first year of optimization to the year 2025 . It can be inferred from the estimated levels of saturated thickness and pumping lift shown in Table 1, that 
Table 4

Production value of crops in the Southern High Plains Region (\$million)

\begin{tabular}{lllll}
\hline Year & Cotton & Corn/grain sorghum & Wheat & Total \\
\hline 1996 & 1053.3 & 240.6 & 79.5 & 1373.4 \\
2000 & 1238.3 & 212.8 & 57.6 & 1508.6 \\
2005 & 1252.7 & 193.7 & 59.6 & 1506.0 \\
2010 & 1242.3 & 179.1 & 66.5 & 1487.8 \\
2015 & 1219.7 & 170.7 & 70.2 & 1460.6 \\
2020 & 1194.6 & 161.0 & 72.8 & 1428.4 \\
2025 & 1169.8 & 149.6 & 75.2 & 1394.5 \\
\hline
\end{tabular}

the greater the change in well pumping lift and saturated thickness, the faster the movement towards dryland crop production.

The estimated production values for cotton, corn/grain sorghum, and wheat are depicted in Table 4. The baseline year of 1996 represents the initial optimal solutions for the dynamic optimization models. The optimal solutions for the baseline year are used to facilitate comparisons to other years in the time horizon. The total production values of crops increase from 1996 to 2000 because of increased cotton production as cotton is substituted for corn/grain sorghum and wheat. From the peak in the year 2000 , the production value of crops declines by $7.5 \%$ in the year 2025 . Cotton production value increases by $18.9 \%$ from 1996 to 2005 and then declines, yet the overall increase from 1996 through 2025 was $15.8 \%$. Corn/grain sorghum production values decline throughout the period by $38 \%$ from 1996 through 2025 . Wheat production value declines by $5.4 \%$ over the same period. Hale, Parmer, Castro, Lamb, Terry and Lubbock Counties made up approximately $50 \%$ of the total crop production value across all the years.

The increase in the production value of crops from the 1996 baseline year to the year 2000 is due to a shift in cropping patterns toward increased cotton production. The relative profitability of cotton compared to other crops and the decreased water requirement of cotton help contribute to the cotton acreage increase and increase in overall production value of crops. However, the total crop production value declines following the year 2000 as the reduction in the irrigation availability impacts the total crop production as crop acreage shifts toward dryland production.

\subsection{Aggregated IMPLAN results}

Direct, indirect, induced and total economic impacts resulting from crop production value in the SHP are presented in Table 5. The direct impacts represent the estimated value of production for the four crops included in the analysis. Indirect impacts represent the response of all industries within the region caused by industries purchasing from other industries as the dollars of crop value move through the economy. Induced impacts represent the response of all industries within the region caused by the expenditures of new household income generated by the direct and indirect effects (Minnesota IMPLAN Group, 1996). These results indicate that the region is expected to experience a decline in the economic contribution of the crop production sectors stemming from reduced crop production starting in the year 2000. The total economic impacts for 
Table 5

Economic impacts of crop production values for the Southern High Plains Region (Smillion)

\begin{tabular}{lllll}
\hline Year & Direct & Indirect & Induced & Total \\
\hline 1996 & 1373.4 & 686.4 & 252.7 & 2312.6 \\
2000 & 1508.6 & 757.8 & 281.1 & 2547.5 \\
2005 & 1506.0 & 757.7 & 281.1 & 2544.7 \\
2010 & 1487.8 & 749.3 & 277.6 & 2514.7 \\
2015 & 1460.6 & 735.8 & 272.4 & 2468.8 \\
2020 & 1428.4 & 720.0 & 266.3 & 2414.7 \\
2025 & 1394.5 & 703.3 & 260.0 & 2357.8 \\
\hline
\end{tabular}

the region decline by approximately $\$ 190$ million from the peak value in the year 2000 . The direct impacts of the changes in crop production value decrease by $7.6 \%$ from the high in the year 2000 . Though the economic impacts of the crop production sectors remained positive compared to the 1996 baseline, the analysis suggests a downtrend over time in their contributions to the regional economy.

\section{Conclusions}

The results of this study support the conclusion that as the saturated thickness of the Ogallala aquifer diminishes and pumping lifts of irrigation wells increase, regional cropping patterns in the SHP will begin to shift toward more dryland agriculture. As water availability decreases, farmers will be expected to reevaluate traditional cropping patterns. When faced with reduced water availability, the results indicate that the optimal solution for producers would be to shift their focus to those crops that require less water and to adopt the most efficient irrigation technologies.

Irrigated and dryland cotton were consistently the optimal choices. In comparing the net returns of all possible combinations of crops and technology, irrigated cotton surpasses all other crops. Although irrigated corn displayed high levels of gross returns, irrigation requirements and the associated costs of production caused its acreage to diminish within the region. The low profitability of irrigated and dryland grain sorghum and wheat causes production of these crops to decrease, although dryland wheat production increases in the latter years of the time horizon.

The results point to the conclusion that cotton is "king" in the SHP region and should be regarded as the crop of choice for producers. Yet, this analysis does not take into consideration the threat of boll weevil infestations to an economy dominated by cotton production or possible changes in relative crop prices in the future. The results of this analysis are predicated on the solutions of the dynamic optimization models, and implicitly assume that farmers will produce at the optimal level, which implies a willingness to make a transition to dryland farming and adopt more efficient irrigation technology. Additionally, the optimization models are based on the assumption that as long as there are positive net returns to an enterprise, a farmer will continue to produce, which is not necessarily the case. Recognizing these limitations, the results suggest important trends in the impact of agricultural production on the regional economy from a declining irrigation groundwater resource. 
Not only will the economic sectors facing decreasing agricultural production be affected, but the economy as a whole in the SHP will be affected due to the interdependence among all industries. Once regional agricultural production peaks and begins to decline through diminished irrigated acreage, the contribution of the crop production sectors to the SHP economy will be expected to decline. The direct effects from agricultural production will be reduced as dryland crops with their associated lower yields replace higher yielding irrigated crops. In turn, this reduction in the final demand within the agricultural sectors will ripple through the regional economy and affect virtually everyone within the region to some degree through the indirect and induced effects of a change in final demand. The overall direction of the regional economy as the groundwater resource is depleted may well depend on the ability of other non-agricultural sectors of the economy to offset the reduced economic activity contributed by agriculture.

The results of this study have implications regarding resource policy and management of the Ogallala aquifer. The importance of irrigated agriculture to the regional economy and the associated negative impacts on the regional economy from a decline in agricultural production may influence future resource policy direction. Programs to provide loans to farmers to assist in adopting more efficient irrigation technologies have been implemented. One policy implication may relate to the number of irrigation wells that may be drilled. As the gross pumping capacity declines, one response of farmers could be to increase the number of wells, therefore, increasing the rate of depletion.

\section{Acknowledgements}

Funding for this project was provided by the High Plains Underground Water Conservation District No. 1, the Texas Water Development Board and the College of Agricultural Sciences and Natural Resources, Texas Tech University. The authors would like to thank Emmett Elam and Steve Teal for their comments and suggestions. Texas Tech University, College of Agricultural Sciences and Natural Resources Publication T-1-483.

\section{References}

Feng, Y. (1992). Optimal intertemporal allocation of groundwater for irrigation in the Texas High Plains. Unpublished Diss., Department of Agricultural Economics, Texas Tech University, Lubbock, TX.

High Plains Underground Water Conservation District No. 1. (1996). The cross section. Vol. 42, No. 11. High Plains Underground Water Conservation District No. 1., Lubbock, TX.

High Plains Underground Water Conservation District No. 1. (1997). The Ogallala aquifer. High Plains Underground Water Conservation District No. 1., Lubbock, TX.

High Plains Underground Water Conservation District No. 1. (1999). The cross section. Vol. 45, No. 3. High Plains Underground Water Conservation District No. 1., Lubbock, TX.

Minnesota IMPLAN Group, Inc. (1996). IMPLAN professional. Stillwater, MN: Minnesota IMPLAN Group.

Minnesota IMPLAN Group, Inc. (1997). IMPLAN System (1995 data and software). Stillwater, MN: Minnesota IMPLAN Group.

Olson, D., \& Lindall, S. (1997). Implan professional software, analysis, and data guide. Stillwater, MN: Minnesota IMPLAN Group. 
Segarra, E., \& Feng, Y. (1994). Irrigation Technology Adoption in the Texas High Plains. Texas Journal of Agriculture and Natural Resources, 7, 71-83.

Texas Agricultural Extension Service. (1996). Texas crop enterprise budgets-Texas South Plains District. Bulletin B1241. College Station, TX: Texas A\&M University System.

Texas Agricultural Statistics Service. (1998). Texas Agricultural Statistics 1997. Bulletin 256. Austin, TX: Texas Agricultural Statistics Service.

Texas Water Development Board. (1993). The High Plains aquifer system of Texas, 1980-1990 overview and projections. Report No. 341. Austin, TX: Texas Water Development Board.

Texas Water Development Board. (1996). Surveys of irrigation in Texas 1958, 1964, 1969, 1974, 1979, 1984, 1989, and 1994. Report No. 347. Austin, TX: Texas Water Development Board.

Texas Water Development Board. (1997). Water For Texas-Vol. II. Technical planning appendix. Document No. GP6-2. Austin, TX: Texas Water Development Board.

USDA. (1999). 1997 Census of agriculture - Texas State and county data. Vol. 1, Geographic area series. Part 43A. US Department of Agriculture. 